\title{
Artikel
}

\section{De Gedragscode Afhandeling Beroepsziekteclaims: een stap vooruit}

mr. H. de Hek*

\section{Waar gaat het om?}

Werknemers die ziek worden door hun werk - die dus een beroepsziekte ${ }^{1}$ oplopen - hebben recht op vergoeding door hun werkgever van de schade die zij lijden, tenminste wanneer die werkgever zijn zorgplicht voor een veilige werkomgeving heeft geschonden (art. 7:658 BW).

Dat is gemakkelijk opgeschreven, maar de praktijk is veel weerbarstiger. Uit diverse onderzoeken ${ }^{2}$ blijkt dat het uitermate ingewikkeld is voor een werknemer met een beroepsziekte om de schade te verhalen. Van de naar schatting 25.000 jaarlijkse beroepsziektezaken zijn er naar schatting 4.500 potentiële beroepsziekteclaims. Daarvan worden er maar ongeveer 500 tot 700 per jaar ingesteld. ${ }^{3}$

Dat is niet voor niets. Als de ziek geworden werknemer zijn werkgever al aansprakelijk durft te stellen, moet hij natuurlijk nog maar afwachten of de aansprakelijkheid wordt erkend. Dat gebeurt, naar mijn inschatting, aan-

* $\quad$ Bert de Hek is senior raadsheer bij het hof Arnhem-Leeuwarden en redacteur van dit tijdschrift.

1. Het Nederlands Centrum voor Beroepsziekten (NCvB) definieert een beroepsziekte als 'een ziekte of aandoening als gevolg van een belasting die in overwegende mate in arbeid of arbeidsomstandigheden heeft plaatsgevonden'.

2. Uit de veelheid van literatuur en rapporten noem ik: R. Knegt e.a., Verhaal van werkgerelateerde schade, Amsterdam: HSI/UvA september 2012, M. de Groot \& S.D. Lindenbergh, Naar een Gedragscode Afhandeling Beroepsziekteclaims?, Rotterdam: Erasmus School of Law 2018 en het rapport van de Commissie Vergemakkelijking schadeafhandeling beroepsziekten, Stof tot nadenken. Stap vooruit, maak werk van preventie en erkenning, 2020

3. Kamerstukken // 2018/19, 25883, nr. 389, p. 2 zienlijk minder vaak dan bij andere aansprakelijkheden. Wordt de aansprakelijkheid niet erkend en zet de werknemer toch door, dan belandt hij al snel in een complexe, langdurige en kostbare procedure. In een van de hiervoor vermelde onderzoeken wordt uitgegaan van een gemiddelde duur van 5,3 jaar en van afhandelingskosten tussen de $€ 15.000$ en $€ 70.000{ }^{4}$

De afgelopen jaren zijn verschillende initiatieven ontwikkeld om de schadeafwikkeling van beroepsziektezaken vlot te trekken. Op een van deze initiatieven, ontwikkeld door de Letselschaderaad, wordt in dit artikel ingegaan. Het betreft het opstellen van de Leidraad Afwikkeling Beroepsziektezaken, een leidraad die in november 2020 is gepresenteerd.

\section{Knelpunten in beroepsziektezaken}

Waarom is het zo ingewikkeld om schade door een beroepsziekte te verhalen? Om het antwoord op die vraag te kunnen vinden, is het nodig om eerst - kort - te bespreken welke eisen gelden voor de toewijsbaarheid van een vordering tot vergoeding van deze schade. Die eisen zijn te vinden in het al genoemde artikel 7:658 BW. Artikel 7:658 lid 1 BW legt op de werkgever de verplichting te zorgen voor de veiligheid van de werkomgeving van de werknemer. Uit de rechtspraak van de Hoge Raad ${ }^{5}$ blijkt dat deze zorgplicht vergaand is. Van de werkgever wordt veel gevraagd. Uit artikel 7:658 Arbeidsrecht Thematisch, aant. 2 op 7:658 BW en Y.R.K. Waterman, SDU Commentaar Arbeidsrecht Artikelsgewijs, aant. 1 op 7:658 BW. 
lid 2 BW blijkt vervolgens dat de werkgever aansprakelijk is voor de schade die de werknemer lijdt in de uitoefening van zijn functie, tenzij de werkgever aantoont dat hij zijn zorgplicht is nagekomen.

Een eerste vereiste voor toewijzing van de vordering van de werknemer is dat de werknemer schade heeft geleden in de uitoefening van zijn werkzaamheden. Vereist is ook dat de werkgever zijn zorgplicht heeft geschonden. Stelplicht en bewijslast van de nakoming van de zorgplicht rusten trouwens op de werkgever. Het derde vereiste is dat deze schade in causaal verband staat tot de zorgplichtschending van de werkgever.

Bij de 'klassieke arbeidsongevallen', zoals een hand in een machine en de val van een steiger, staat meestal niet ter discussie dat de werknemer schade heeft geleden in de uitoefening van de werkzaamheden. De juridische pijn zit'm dan ook niet in dit vereiste. Natuurlijk kunnen discussies ontstaan over randgevallen - hoe zit het bijvoorbeeld met schade die is ontstaan tijdens bedrijfsuitjes of personeelsfeestjes - en kan discussie over de vraag of het ongeval waarvan de werknemer stelt dat het op het werk heeft plaatsgevonden, ook daadwerkelijk heeft plaatsgevonden, maar die discussies zijn geen regel maar uitzondering. Als eenmaal is vastgesteld dat het gestelde bedrijfsongeval heeft plaatsgevonden, vormt het causaal verband tussen de schade en het ongeval eigenlijk nooit een probleem. ${ }^{6}$ Bij juridische geschillen over dit soort arbeidsongevallen draait het meestal om de zorgplichtschending. Overigens rusten op de werkgever de stelplicht en de bewijslast dat hij zijn zorgplicht is nagekomen.

Bij beroepsziekten ligt het zwaartepunt van de discussie meestal bij het eerstgenoemde vereiste. De vraag of de werknemer schade heeft geleden, ziek is geworden, in de uitoefening van de functie - anders geformuleerd: of de werknemer bij zijn werk een beroepsziekte heeft opgelopen - staat daar centraal. Dat is een ingewikkelde vraag, alleen al omdat het in veel gevallen niet zo gemakkelijk is vast te stellen of de gezondheidsklachten waaraan iemand lijdt, in overwegende mate in de werksfeer zijn ontstaan. Om dat te kunnen vaststellen is niet alleen informatie nodig over de ziekte of gezondheidsklachten, maar ook over de omstandigheden waaronder gewerkt is of wordt - welke belasting of blootstelling vindt daar plaats - en moet er een verband gelegd kunnen worden tussen de vastgestelde gezondheidsklachten en de belasting of blootstelling. Het vaststellen van een beroepsziekte vergt dan ook een causale afweging. En die is vaak lastig te maken. Het is dan ook niet verwonderlijk dat de knelpunten in beroepsziektezaken samenhangen met het schadevereiste, de vaststelling dat sprake is van een beroepsziekte.

In het onderzoek dat is voorafgegaan aan de Leidraad Afwikkeling Beroepsziektezaken, zijn op dat punt drie

6. Ik doel dan natuurlijk op het causaal verband tussen het ongeval en het bestaan van schade, niet op het causaal verband tussen het ongeval en de gezondheidsklachten die de werknemer stelt te hebben. knelpunten onderscheiden, ${ }^{7}$ te weten de vaststelling van de blootstelling, de vaststelling van de causaliteit (tussen blootstelling en gezondheidsklachten) en de inschakeling van externe deskundigen. Met deze knelpunten hangen andere knelpunten samen, zoals de lange duur van de afwikkeling van een beroepsziekteclaim en de hoge afwikkelingskosten. Dat de rechtspraak van de Hoge Raad over beroepsziekteclaims, niet geheel ten onrechte, als ingewikkeld wordt ervaren, ${ }^{8}$ ook een knelpunt, helpt bij dit alles niet mee.

Het is zinvol nog even in te gaan op de drie eerstgenoemde knelpunten, omdat de Leidraad Afwikkeling Beroepsziektezaken tegemoet wil komen an die knelpunten.

- Het is vaak ingewikkeld om vast te stellen welke blootstelling of belasting de werknemer heeft gehad. De reden daarvan is allereerst dat er vaak behoorlijk wat tijd is verlopen tussen de blootstelling en het instellen van de claim. Beroepsziekten ontstaan doorgaans niet van het ene op het andere moment, maar hebben meestal een sluipend ontstaansmechanisme; vaak merkt de werknemer pas na geruime tijd dat hij serieuze klachten heeft, soms is sprake van een lange latentietijd tussen de blootstelling en het moment dat de ziekte zich openbaart; bij mesothelioom is die latentietijd bijvoorbeeld dertig jaar. Het is vaak niet eenvoudig om een blootstelling of belasting van jaren geleden vast te stellen: de arbeidsomstandigheden zijn gewijzigd, collega's die iets kunnen vertellen over de arbeidsomstandigheden zijn er niet meer en relevante informatie zoals een risico-inventarisatie en een lijst met stoffen waarmee gewerkt is, zijn inmiddels vernietigd.

- De vaststelling van de causaliteit is ingewikkeld, zeker wanneer relevante informatie over de blootstelling ontbreekt. Dat heeft te maken met het al genoemde sluipende karakter van veel beroepsziekten, maar ook met het feit dat veel van die ziekten een multicausaal karakter hebben.

- Vanwege de complexiteit van het vaststellen van de blootstelling en de causaliteit moeten in veel gevallen meerdere deskundigen worden ingeschakeld. Te denken valt aan een medisch specialist met expertise op het terrein van de ziekte en een blootstellingsdeskundige, bijvoorbeeld een toxicoloog. Wie ervaring heeft met deskundigen in aansprakelijkheidsgeschillen weet dat de ene deskundige de andere (contradeskundige) nogal eens uitlokt en dat het veel tijd kost om een deskundige te vinden, waarmee beide partijen kunnen instemmen. Het inschakelen van een deskundige heeft dan ook meestal geen matigend effect op de duur en de kosten van de afhandeling van een schadeclaim.

7. Zie De Groot \& Lindenbergh, 2012, p. 14-39. Voor een samenvatting: M. de Groot, 'Naar een Gedagscode Afhandeling Beroepsziekteclaims?', AP 2019/1.

8. De Groot \& Lindenbergh, 2012, p. 31 en 32. Zij verwijzen naar de '7juni-arresten', HR 7 juni 2013, ECLI:NL:HR:2013:BZ1717 en ECLI:NL:HR:2013:BZ1721) en naar HR 6 april 2018, ECLI:NL:HR: 2018:536). 


\section{Haagse initiatieven}

Dat de afwikkeling van een beroepsziektezaak een moeizaam gebeuren is, is de politiek niet ontgaan. De laatste jaren zijn vanuit 'Den Haag' dan ook diverse initiatieven ontplooid die de bedoeling hadden om de afwikkeling te versnellen en de positie van slachtoffers te verbeteren. Enkele initiatieven worden hierna besproken.

Het accountantskantoor $\mathrm{PwC}_{\mathrm{w}}$ heeft van de minister van Sociale zaken en Werkgelegenheid (hierna: de minister) de opdracht gekregen de mogelijkheid te onderzoeken van een ECCB: een onafhankelijk instituut dat partijen gezamenlijk voor de beoordeling van de causaliteit tussen werk en ziekte kunnen inschakelen. Dat heeft in mei 2015 geresulteerd in een rapport van $\mathrm{PwC}_{\mathrm{w}}{ }^{9}$ dat - enigszins voorspelbaar: een adviesvraag bij de consultancytak van zo'n groot kantoor leidt al snel tot een rapport met de conclusie dat nader onderzoek nodig is gevolgd werd door een vervolgrapport van $\mathrm{PwC}$ in 2016. Daar strandde het schip. Vanwege het ontbreken van draagvlak kwam het niet tot de oprichting van een ECCB, moest de minister van Sociale Zaken en Werkgelegenheid aan de Tweede Kamer melden. ${ }^{10}$

In juli 2019 stelde de staatssecretaris van Sociale Zaken en Werkgelegenheid (hierna: de staatssecretaris) de commissie Vergemakkelijking Schadeafhandeling Beroepsziekten in, ${ }^{11}$ in de (parlementaire) volksmond beter bekend als de Commissie Heerts (naar haar voorzitter). De Commissie Heerts presenteerde in maart 2020 haar rapport met de titel 'Stof tot nadenken' en de ondertitel 'Stap vooruit, maak werk van preventie en erkenning.' De Commissie Heerts deed aanbevelingen op een viertal terreinen. De aanbevelingen kunnen als volgt worden samengevat: ${ }^{12}$

- Investeer in betere preventie door bedrijven.

- Investeer in een stevige infrastructuur voor kennis, diagnose en behandeling van beroepsziekten.

- Introduceer een algemene tegemoetkoming voor werkenden die aan een beroepsziekte lijden als gevolg van een blootstelling aan gevaarlijke stoffen.

- Introduceer een passende boete voor werkgevers en opdrachtgevers die hun zorgplicht niet nakomen.

In een brief van 13 juli 2020 aan de Tweede Kamer ${ }^{13}$ liet de staatssecretaris weten dat de regering kan instemmen met de aanbevelingen van de Commissie Heerts en die verder wil uitwerken. Over de aanbeveling om te investeren in een stevige infrastructuur voor kennis, diagnose en behandeling van beroepsziekten, merkte de staatssecretaris op dat zij op korte termijn een 'verkenner' zal benoemen die de taak krijgt nader te onderzoeken en uit te werken wat nodig is om tot deze infrastructuur te komen en hoe die kan worden ingericht.

9. Zie voor een bespreking van dit rapport: G.J. Knotter, TLP 2016/104.

10. Kamerstukken I/ 2016/17, 25883, nr. 289.

11. Kamerstukken // 2018/19, 25883, nr. 352

12. Vermeld in de samenvatting van het rapport (p. 11-13) en verder in het rapport uitgewerkt.

13. Kamerstukken // 2019/20, 25883, nr. 389.
Een beetje cynicus zal met deze toezegging de hoop op een spoedige verbetering van de infrastructuur verliezen: 'over die verkenner horen we waarschijnlijk nooit meer iets'. Dat is veel te negatief gedacht, want inmiddels is de aangekondigde verkenner er. In november 2020 is voormalig minister Bruins tot verkenner benoemd. ${ }^{14}$ In de genoemde brief van de staatssecretaris wordt opgemerkt dat een van de gevolgen van een verbeterde kennisinfrastructuur zal zijn dat de beoordeling van de medische causaliteit er sneller en beter op zal worden: ${ }^{15}$

'Bovendien zal de beoordeling van de medische causaliteit van ziekten, een van de voorgestelde taken van de kennisinfrastructuur, eraan bijdragen dat een slachtoffer sneller uitsluitsel en erkenning krijgt. Dit is een belangrijk verschil met de huidige situatie, waarbij de bewijsvoering zich, mede door het multicausale karakter van beroepsziekten, kenmerkt als langdurig, problematisch, en kostbaar. Het niet (tijdig) onderkennen van beroepsziekten leidt er ook toe dat gezondheidsrisico's voor werkenden lang blijven voortbestaan. Een vaste lijst met stoffengerelateerde beroepsziekten is daarbij inderdaad behulpzaam bij de beoordeling of, in een specifiek geval, betrokkene lijdt aan een beroepsziekte als gevolg van het werken met gevaarlijke stoffen op het werk. Deze lijst kan meegroeien met nieuwe informatie op dit terrein.'

Het rapport van de Commissie Heerts en de kabinetsreactie op dat rapport bevatten, gezien het voorgaande, geen voorstellen die rechtstreeks tot gevolg hebben dat de afwikkeling van beroepsziekteclaims gemakkelijker zullen verlopen. Hooguit is op (lange) termijn - als de verkenner zijn werk doet door met concrete plannen te komen en die plannen zijn uitgewerkt - indirect een positief effect te verwachten.

$\mathrm{Na}$ twee initiatieven lijkt een derde initiatief tot verbetering van de positie van de slachtsoffers van beroepsziekten op het eerste gezicht te veel van het goede. Dat is toch niet het geval. Het onafhankelijke instituut voor de beoordeling van causaliteit is er immers niet gekomen en de aanbevelingen van de Commissie Heerts leiden hooguit op termijn tot het vergemakkelijken van de vaststelling van de causaliteit tussen (blootstelling op het) werk en ziekte. Alle ruimte dus voor een derde initiatief dat speciaal gericht is op het op korte termijn vergemakkelijken van die vaststelling. Ook bij dat initiatief was het ministerie van Sociale Zaken en Werkgelegenheid actief betrokken. Het faciliteerde De Letselschade Raad om een gedragscode op te stellen waarin afspraken kunnen worden neergelegd over de wijze waarop een beroepsziekteclaim wordt afgehandeld. ${ }^{16}$ Het project kende twee fases, een inventariserende fase, uitgevoerd door de Erasmus School of Law, onder leiding van prof. Siewert Lindenbergh, en een creërende fase. In de oriënterende fase werden de kansen voor een gedragscode verkend.

14. Kamerstukken I/ 2020/21, 25883, nr. 393.

15. Kamerstukken I/ 2019/20, 25883, nr. 389, p. 5-6.

16. Kamerstukken // 2016/17, 25883, nr. 295. 
Het resulteerde in november 2018 in een rapport. ${ }^{17}$ De resultaten van de oriënterende fase boden voldoende perspectief om met de creërende fase te beginnen. In deze fase, die ook weer werd begeleid door enkele wetenschappers onder leiding van Siewert Lindenbergh, heeft een breed samengetelde werkgroep onder aansturing van een stuurgroep een gedragscode opgesteld, de Leidraad Afwikkeling beroepsziekten ${ }^{18}$ (hierna: de Leidraad). De Leidraad is in november 2020, twee jaar na het rapport waarmee de oriënterende fase werd afgesloten, gepresenteerd. Op zich al een knappe prestatie, gezien de complexiteit van het onderwerp, de niet altijd gelijke belangen, het aantal organisaties dat bij het project betrokken is en, in de laatste maanden van het project, de beperkingen vanwege de coronapandemie.

\section{Het uitgangspunt van de Leidraad}

De opstellers van de Leidraad hebben niet gekozen voor het stellen van materiële normen, maar voor adviezen over het op orde brengen van de (buitengerechtelijke) procedure bij een claim van een werknemer. Ze hebben een stappenplan ontwikkeld, waarin werknemer en werkgever (in de praktijk meestal de verzekeraar van de werkgever) systematisch de voor een goede beoordeling van de claim noodzakelijke informatie proberen te verzamelen. Dat doen ze door zo veel mogelijk samen te werken in een sfeer van onderling vertrouwen. In de samenvatting van de Leidraad wordt opgemerkt dat deze samenwerking een houding van openheid en vertrouwen veronderstelt en 'het gedeelde belang bij helderheid, voortvarendheid en oplossingsgerichtheid' dient.

Mooie woorden die uitdrukking geven aan een op zich niet eens zo hooggestemd ideaal; het gaat (nog) niet om recht en gerechtigheid, maar heel 'down to earth' om een pragmatische en efficiënte samenwerking. Maar voor wie een aantal dossiers in beroepsziektezaken, vaak meer dan tien jaar na de aansprakelijkheidsstelling, ter beoordeling voor zich krijgt, is ook het streven naar samenwerking al best een hooggestemd ideaal. De samenwerking en het belang bij helderheid en voortvarendheid druipen meestal niet van zo'n dossier af. Een beetje cynicus - daar heb je'm weer - zal denken dat er zaken zijn waarin niet beide partijen belang hebben bij volledige openheid, zeker niet wanneer die openheid ertoe zal leiden dat het ingenomen standpunt niet houdbaar blijkt te zijn en er fors betaald moet worden, of een vordering tot schadevergoeding in rook opgaat. Anderzijds heeft de Letselschaderaad al wel enkele gedragscodes ontwikkeld waarin ook wordt uitgegaan van samenwerking op basis van onderling vertrouwen, de

17. M. de Groot \& S.D. Lindenbergh, 2018. Zie voor een verkorte weergave: $M$. de Groot, AP 2019/1.

18. Te vinden op en te downloaden van de site van De Letselschade Raad, www.deletselschaderaad.nl.
Gedragscode Behandeling Letselschade (GBL), de Medische Paragraaf van de GBL en de Gedragscode Openheid medische incidenten (GOMA). Deze gedragscodes zijn over het algemeen positief ontvangen in de letselschadepraktijk en lijken een positief effect te hebben. ${ }^{19}$

De tijd zal leren of de Leidraad vanuit een al te idealistische verwachting is opgesteld. Aan het stappenplan dat de Leidraad bevat, zal het niet liggen. Daar is niets vaag of idealistisch aan. Het is een heel concreet en praktisch stappenplan dat wanneer beide partijen van goede wil zijn en aan een aantal randvoorwaarden is voldaan, alles in zich heeft om heel goed te kunnen werken.

\section{De randvoorwaarden in de Leidraad}

De Leidraad bevat na een inleidende paragraaf waarin onder meer het hiervoor besproken uitgangspunt wordt geformuleerd, enkele centrale begrippen worden uitgelegd en wat algemene opmerkingen worden gemaakt, een drietal aanbevelingen - hoewel dat woord niet wordt gebruikt - voor het afwikkelingsproces. Ze zijn geformuleerd op de manier waarop ook de gedragsregels in de GBL zijn geformuleerd, in de vorm van een normatieve uitspraak die vervolgens wordt toegelicht. De aanbevelingen lijken te fungeren als randvoorwaarden voor een succesvol doorlopen van het stappenplan, dat pas na die aanbevelingen of gedragsregels uiteen wordt gezet. Het gaat om de volgende aanbevelingen:

- 'Werknemer en werkgever laten zich ieder bijstaan door een op het gebied van beroepsziekteclaims deskundige. ${ }^{20}$

- 'De belangenbehartiger van de werknemer licht de werknemer voor over de bijzondere aard van beroepsziektezaken en de daarmee gepaard gaande (verwachte) duur en kosten van het traject.'21

- 'Partijen zijn samen verantwoordelijk voor een voortvarende behandeling van de zaak en maken afspraken over de te hanteren termijnen. ${ }^{22}$

Deze aanbevelingen spreken voor zich, maar het is toch goed ze op te nemen in de Leidraad, omdat ze in de praktijk geregeld niet in acht worden genomen. De bespreking van de aanbevelingen kan dan ook beknopt blijven.

Terecht wordt in de toelichting op de aanbeveling over de deskundigheid opgemerkt dat het vanwege de complexiteit van de problematiek belangrijk is dat de betrokken adviseurs zich laten bijstaan door professionals die op het gebied van beroepsziekten deskundig zijn. De suggestie dat een belangenbehartiger die zich onvol-

19. Ik formuleer dat wat voorzichtig, omdat ik niet bekend ben met (kwantitatief) onderzoek naar het effect van deze richtlijnen in de letselschadepraktijk.

20. Par. 2 Leidraad

21. Par. 3 Leidraad.

22. Par. 4 Leidraad. 
doende deskundig acht, moet doorverwijzen, is terecht en vloeit ook voort uit de in artikel 7:401 BW neergelegde algemene zorgplicht van de opdrachtnemer. Een goede professional kent zijn beperkingen.

Dat de aanbeveling om te doen aan 'verwachtingenmanagement' zich alleen richt tot de belangenbehartiger van de werknemer, is wellicht verklaarbaar tegen de achtergrond van het feit dat achter de werkgever in de meeste gevallen een verzekeraar staat die zelf de regie heeft. Verwachtingenmanagement is dan niet aan de orde. Voor het evenwicht zou het echter helemaal niet zo vreemd zijn geweest om ook de werkgever en diens verzekeraar aan te sporen aan verwachtingenmanagement te doen. Zeker wanneer dat verwachtingenmanagement ook bestaat uit een kosten-batenanalyse, waarbij in kaart wordt gebracht wat de baten (voor de werknemer de te verkrijgen schadevergoeding, voor de werkgever de maximaal te besparen schadevergoeding) en anderzijds wat de kosten (in termen van geld, tijd en inspanning) zijn.

Het is mij al een paar keer overkomen dat ik glazig word aangekeken wanneer ik bij een comparitie in hoger beroep (vaak meer dan vijf jaar na de aansprakelijkheidsstelling) vraag naar de schadeomvang; daar hebben partijen zich in al die jaren strijd over de aansprakelijkheid nog niet mee beziggehouden. De baten zijn dan duidelijk niet in kaart gebracht. Als dat alsnog gebeurt, blijkt in een aantal gevallen dat de schade betrekkelijk gering is. Dat is niet zo vreemd omdat een werknemer valk al op leeftijd is wanneer hij uitvalt door een beroepsziekte. Wanneer beide partijen hun baten (schadevergoedingsvordering dan wel te besparen uitkering) eerder in kaart zouden hebben gebracht, zouden ze wellicht niet aan het traject begonnen zijn. Wat mij betreft, wordt in een volgende versie van de Leidraad toegevoegd dat ook de werkgever/verzekeraar er goed aan doet om zich voordat het hele traject in gang wordt gezet, af te vragen welke verwachtingen hij heeft van de te besparen uitkering. ${ }^{23}$

Over de aanbeveling om te streven naar een voortvarende behandeling valt weinig te zeggen; het is een korte samenvatting van de gedragsregels uit de GBL die er alle toe strekken dat het proces zo spoedig mogelijk verloopt.

\section{Het pièce de résistance van de Leidraad: het stappenplan}

Nadat met de hiervoor besproken aanbevelingen de randvoorwaarden voor het succesvol doorlopen van het stappenplan zijn geformuleerd, wordt het stappenplan zelf in de paragrafen 5 tot en met 8 beschreven. Het gaat om zeven stappen die in de verschillende paragrafen ook worden toegelicht. Hierna worden ze besproken.

23. Dat geldt trouwens ook bij de afwikkeling van medische claims, waar de GOMA een vergelijkbare aanbeveling (aanbeveling 10) heeft, die zich ook alleen richt tot de belangenbehartiger van de patiënt.
De behandeling van een claim begint natuurlijk altijd met de claim zelf. Daarover gaat stap 1. Die houdt in dat de werknemer zorgt voor een goed onderbouwde aansprakelijkheidsstelling die in elk geval de volgende elementen bevat: een specifieke omschrijving van de arbeidsomstandigheden die tot de (gezondheids)schade hebben geleid, een zo uitgebreid mogelijke onderbouwing van aard en omvang van de gezondheidsschade en de daaruit voortvloeiende schadeposten en een duidelijk beeld van de huidige gezondheidssituatie (inclusief informatie over arbeidsongeschiktheid, beperkingen en eventuele uitkeringssituatie). De aansprakelijkheidsstelling bevat de uitdrukkelijke uitnodiging om de claim in harmonie (aan de hand van de Leidraad) af te handelen. In de toelichting wordt, terecht, opgemerkt dat de werknemer niet verplicht is medische informatie mee te sturen, maar dat het wel gewenst is dat hij de beschikbare stukken vermeldt waarin deze informatie is vastgelegd. In het voorgaande is al gewezen op het belang van informatie over de schadeomvang in een zo vroeg mogelijk stadium. Stap 1 voorziet daar ook in.

Bij stap 2 is de werkgever aan de beurt. De werkgever dient de claim zo spoedig mogelijk te melden bij zijn aansprakelijkheidsverzekeraar, die op zijn beurt bij de werkgever de beschikbare informatie over de blootstelling van de werknemer inwint. Deze informatie wordt gedeeld met de belangenbehartiger van de werknemer. Is er geen verzekeraar, dan schakelt de werkgever een belangenbehartiger in die doet wat de verzekeraar zou hebben gedaan. In de toelichting wordt erop gewezen dat de verzekeraar zich bij het verzamelen van informatie actief opstelt en worden nuttige suggesties gedaan over het soort informatie dat relevant is en hoe die informatie kan worden achterhaald.

$\mathrm{Na}$ de fase van de informatieverzameling en, heel belangrijk, informatie-uitwisseling volgt een gezamenlijk bezoek. Binnen drie maanden na de aansprakelijkheidsstelling, geeft stap 3 aan, nodigt de werkgever/de verzekeraar de werknemer en diens belangenbehartiger uit voor een bezoek aan de werkplek om gezamenlijk de arbeidsomstandigheden in kaart te brengen en om te bezien of overeenstemming bestaat over wat er feitelijk is gebeurd. Het gaat bij het bezoek om de blootstelling en om de door de werkgever getroffen veiligheidsmaatregelen. Partijen maken gezamenlijk een verslag van het bezoek. Dat bezoek is, volgt uit de toelichting, geen 'heilig moeten'. Het moet natuurlijk wel zinvol zijn en dat is niet het geval wanneer op voorhand duidelijk is dat er bij de (voormalige) werkplek geen relevante informatie meer te vinden valt, bijvoorbeeld omdat de arbeidsomstandigheden na de periode van de blootstelling drastisch zijn gewijzigd. Van belang is - en dat onderwerp komt hierna vaker terug - dat zolang de aansprakelijkheid niet vaststaat werknemer en werkgever de eigen kosten van deze stap, net als die van de vorige stappen, zelf dragen.

$\mathrm{Na}$ deze stap volgt, in stap 4, een evaluatie, of beter: de eerste evaluatie, want er volgen er meer als het stappenplan verder gevolgd wordt. Als het bezoek heeft plaatsgevonden, hebben partijen informatie over de blootstel- 
ling en de arbeidsomstandigheden verkregen. De informatie is afkomstig uit de door beide partijen aangeleverde gegevens en uit de gegevens die het bezoek, inclusief na mogelijk naar aanleiding van het bezoek verricht aanvullend onderzoek, heeft opgeleverd. Stap 4 voorziet erin dat partijen binnen zes weken na het werkplekbezoek gezamenlijk de balans opmaken met betrekking tot de vraag in hoeverre de werknemer in zijn werk is blootgesteld aan een gezondheidsrisico en welke maatregelen de werkgever heeft getroffen om de blootstelling te voorkomen. In theorie zijn er vier mogelijkheden:

a. Partijen zijn het erover eens dat er (hoogstwaarschijnlijk) geen sprake is geweest van blootstelling aan een gezondheidsrisico. Het is logisch dat het traject met die conclusie eindigt; aan een van de vereisten voor aansprakelijkheid - het bestaan van een beroepsziekte - is dan immers niet voldaan.

b. Partijen zijn het erover eens dat sprake is geweest van blootstelling van de werknemer aan een gezondheidsrisico en ze zijn het ook eens over de relevante feiten (aard, mate, duur en frequentie) betreffende die blootstelling. Partijen kunnen dan door naar stap 6, over het causaal verband tussen die blootstelling en de gezondheidsklachten.

c. Partijen zijn het wel eens over de feiten, maar niet over het antwoord op de vraag of bij die feiten sprake is van blootstelling aan een gezondheidsrisico. Ze gaan dan door naar stap 5, die betrekking heeft op die vraag.

d. Dan blijft de situatie over dat partijen het ook niet eens zijn over de feiten. Ze leggen dan vast waar ze het wat betreft de feiten wel over eens zijn en ze overleggen over mogelijkheden om de resterende zekerheden over de feiten weg te nemen. Ook bij deze stap dragen partijen, zolang de aansprakelijkheid niet vaststaat, ieder de eigen kosten.

Stap 5 hoeven partijen alleen te zetten wanneer ze het wel eens zijn over de feiten, maar niet over het antwoord op de vraag of de werknemer bij die feiten is blootgesteld aan een gezondheidsrisico (mogelijkheid c bij stap 4). In die situatie schakelen partijen gezamenlijk binnen twee maanden een deskundige in om dit te beoordelen door een blootstellingsonderzoek ${ }^{24}$ uit te voeren. Ze dragen de kosten van deze deskundige (vooralsnog - daarover hierna meer) gezamenlijk. Stap 5 voorziet in twee mogelijkheden:

a. Uit het onderzoek blijkt dat geen sprake is geweest van blootstelling aan een gezondheidsrisico. Bij deze uitkomst valt het doek voor de claim en eindigt het traject.

b. Uit het onderzoek blijkt dat sprake is geweest van blootstelling aan een gezondheidsrisico. Partijen gaan dan door naar stap 6 , over het causaal verband tussen deze blootstelling en de gezondheidsklachten.
Het is de vraag of deze dichotomie - uit het onderzoek blijkt wel of niet dat sprake is geweest van blootstelling aan een gezondheidsrisico - wel zo voor de hand ligt als op het eerste gezicht lijkt. In veel letselschadezaken markeert het rapport van een gezamenlijke deskundige (benoemd door partijen of door de rechter) vaker het begin dan het einde van een discussie. Het komt naar mijn inschatting vaker voor dat een van de partijen zich niet neerlegt bij de conclusies van een deskundige dan dat beide partijen deze conclusies accepteren en daar consequenties aan verbinden. Het stappenplan lost dat probleem niet op. Het zou dan ook zo maar kunnen dat veel gezamenlijke trajecten bij stap 5 eindigen, als het rapport van de deskundige op tafel ligt. Misschien al eerder zelfs, want het is vaak een hele klus voor partijen om een deskundige te vinden in wie zij beide vertrouwen hebben. Dat geldt zeker ook voor blootstellingsdeskundigen. Natuurlijk is het mogelijk om te proberen het draagvlak van een deskundigenonderzoek te vergroten door twee of meer deskundigen te benoemen, maar aan deze optie zitten nadelen. De kosten zullen nog hoger worden en het zal niet altijd gemakkelijk zijn om deskundigen te vinden die met elkaar willen en kunnen samenwerken. Wanneer de deskundigen er ook nog niet in slagen tot eenstemmige conclusies te komen, zijn partijen nog verder van huis. ${ }^{25}$

Als partijen, al dan niet na een blootstellingsonderzoek, tot de conclusie komen dat sprake was van blootstelling van de werknemer aan een gezondheidsrisico, volgt stap 6. Bij die stap wordt het causaal verband tussen de (vastgestelde) blootstelling aan een gezondheidsrisico en de (kans op) gezondheidsschade bij de werkgever vastgesteld. Het gaat dan om de vraag of aannemelijk is dat de gezondheidsschade van de werknemer het gevolg is van de blootstelling, dan wel om de vraag hoe groot de kans is dat dat het geval is.

Partijen proberen er eerst gezamenlijk uit te komen. In dat verband leggen zij het volledige medische dossier en een inventarisatie van de mogelijke blootstelling aan andere risicofactoren buiten het werk van de werknemer voor aan hun medisch adviseurs. Komen ze er niet in onderling overleg uit, dan benoemen zij binnen twee maanden gezamenlijk een of meer deskundigen om de vraag naar het causaal verband te beoordelen. De kosten van deze deskundigen worden (vooralsnog) weer door partijen ieder voor de helft gedragen.

Bij deze stap kan de werkgever zich ook op het standpunt stellen dat hij heeft voldaan aan zijn zorgplicht. Indien dat het geval is, dan is hij ondanks de blootstelling niet aansprakelijk voor de door de blootstelling veroorzaakte gezondheidsschade. In dat geval kan volgens de toelichting op stap 6 een onderzoek naar het causaal verband achterwege blijven. Logisch, maar wat wanneer partijen het niet eens zijn over de zorgplichtschending? De Leidraad beantwoordt deze vraag 
helaas niet. Het verdient aanbeveling dat in die situatie toch een onderzoek naar het causaal verband plaatsvindt, zodat - als het vervolgens tot een procedure komt - het deskundigentraject afgerond is; dat zal de gerechtelijke procedure aanzienlijk verkorten.

Wat bij stap 5 is opgemerkt over de keuze van de deskundige en het overnemen van de conclusies van de deskundige, geldt ook bij deze stap.

Stap 7 is de laatste stap. Bij deze stap maken partijen binnen zes weken na het causaliteitsonderzoek de balans op. De stap onderscheidt drie mogelijke uitkomsten:

a. De gezondheidsschade is niet veroorzaakt door de vastgestelde blootstelling. Het traject eindigt met die vaststelling.

b. De gezondheidsschade is wel veroorzaakt door de vastgestelde blootstelling aan het gezondheidsrisico. De werkgever is aansprakelijk. Partijen gaan in overleg over de afwikkeling van de schade. In die situatie draagt de werkgever alsnog de volledige kosten van de deskundigenonderzoeken en betaalt hij dus de door de werknemer voorgeschoten helft van die kosten.

c. Er is een niet te verwaarlozen veroorzakingskans. Partijen stellen de aansprakelijkheid van de werkgever vast overeenkomstig die kans en gaan dus uit van proportionele aansprakelijkheid van de werkgever. Vervolgens wordt de schade op basis van die kans afgewikkeld.

\section{Struikelen in het stappenplan}

Uit de beschrijving van het stappenplan volgt al dat het niet vanzelfsprekend is dat de in het stappenplan voorziene stappen daadwerkelijk worden gezet. Ook als beide partijen van goede wil zijn en samen op willen lopen, is er de kans dat ze struikelen. Vooral de inzet van deskundigen waarin het plan voorziet, vormt een potentieel struikelblok.

Allereerst zal het lastig kunnen zijn om deskundigen te vinden met wie beide partijen kunnen instemmen. Dit probleem is niet gemakkelijk oplosbaar. Wellicht zal het op de langere termijn wat gemakkelijker worden, wanneer het werk van de onlangs in aansluiting op het rapport van de commissie Heerts benoemde verkenner vruchten begint af te werpen. Op de kortere termijn staat het partijen natuurlijk vrij om wanneer zij geen overeenstemming bereiken over de benoeming van een deskundige en toch het stappenplan willen blijven volgen, de rechter in te schakelen. Dat kan in elk geval door een procedure tot het houden van een voorlopig deskundigenbericht aanhangig te maken. Verdedigbaar is dat het ook kan door in een deelgeschilprocedure de rechtbank te verzoeken een uitspraak te doen over de vraag welke deskundige moet worden benoemd. ${ }^{26}$

26. Vgl. Rb. Midden-Nederland 25 april 2018, ECLI:NL:RBMNE:2018:1838, Rb. Oost-Brabant 21 januari 2020, ECLI:NL:RBOBR:2020:1481. Zie ook A.F. Collignon-Smit, De deelgeschilprocedure, (BPP nr. 21), Deventer 2019, par. 7.2.6
Vervolgens vormen de kosten van de deskundige een probleem. Hiervoor is er al op gewezen dat de kosten hoog zijn. Ook wanneer de werknemer maar de helft van de kosten voor zijn rekening hoeft te nemen, gaat het al snel om een paar duizend euro. Dat zal in veel gevallen - vooral in situaties waarin de werknemer geen rechtsbijstandsverzekeraar heeft en ook geen aanspraak heeft op rechtshulp van een vakbond - een niet te nemen hindernis zijn. Ook hier kan de gang naar de rechter helpen. Als de werknemer in aanmerking komt voor kosteloze rechtsbijstand, wordt het door hem verschuldigde voorschot op de kosten van een in het kader van een voorlopig deskundigenbericht te benoemen deskundige door het rijk voorgeschoten. ${ }^{27}$ Het betreft echter een voorschot. Na het uitbrengen van het deskundigenrapport bepaalt de rechter wie van de partijen het loon van de deskundige verschuldigd is. ${ }^{28}$ Deze route bevrijdt de werknemer dus niet van het risico dat hij uiteindelijk de helft van de kosten van de deskundige zelf zou moeten dragen.

Op de in de Leidraad gemaakte keuze dat partijen ieder de helft van de kosten dragen, tenzij aansprakelijkheid wordt vastgesteld, valt overigens wel wat af te dingen. Indien vaststaat dat de werkgever niet heeft voldaan aan zijn zorgplicht, is goed verdedigbaar dat ook de buiten rechte gemakte kosten van een onderzoek door een deskundige naar de causaliteit voor rekening van de werkgever komen, ook als achteraf wordt vastgesteld dat geen sprake is van causaal verband. ${ }^{29}$

Ten slotte kunnen partijen struikelen over een verschillende waardering van het onderzoek van de door hen gezamenlijk benoemde deskundige(n). En dat zou maar zo kunnen gebeuren bij het rapport van de blootstellingsdeskundige. Een oplossing is niet gemakkelijk. Natuurlijk kunnen partijen vooraf afspreken dat zij zich zullen neerleggen bij het rapport van de deskundige dat fungeert dan als bindend advies en is daardoor maar zeer beperkt aantastbaar ${ }^{30}-$, maar daarmee worden discussies over de interpretatie van het rapport en de betekenis ervan voor het geschil tussen partijen nog niet voorkomen.

\section{Lopen maar}

Wie vooral struikelblokken ziet, zal nooit gaan lopen. Maar wie ondanks de mogelijkheid om ten val te komen op weg gaat, kan zomaar eens flinke stappen zetten. Wanneer de Leidraad vanuit die laatste, optimistische, houding wordt bezien en gebruikt, kan het partijen zeker helpen gemakkelijker dan anders de eindstreep van een traject tot afwikkeling van een beroepsziekteclaim te halen. En als het ondanks de Leidraad niet gemakkelijk gaat, maakt de Leidraad het traject door de

27. Art. 195 juncto 205 Rv.

28. Art. 205 lid 2 Rv.

29. Vgl. HR 11 juni 2003, ECLI:NL:HR:2003:AF7423 en 13 maart 2015, ECLI:NL:HR:2015:586.

30. Zie art. 7:904 BW 
investering die ze vraagt in de goede verhouding tussen partijen in elk geval minder slopend. Alleen dat is al een stap vooruit. 